\title{
INDONESIAN CAPITAL MARKET REACTION TO COVID-19 AS A GLOBAL PANDEMIC
}

\author{
Novi Syaifatun Kamala ${ }^{1}$, Muhammad Andryzal Fajar ${ }^{2}$ \\ 1,2 Faculty of Economics, Universitas Negeri Yogyakarta, Indonesia \\ *Email Corresponding Author: novikamala9@gmail.com
}

\begin{abstract}
This study aims to obtain empirical evidence of the absence of an average abnormal return, average volume trading activity, and bid-ask spread of stocks in the period around the event of the COVID-19 announcement as a global pandemic. The statement of the COVID-19 as the global pandemic of the World Health Organization (WHO) made the Indonesian capital market touch the lowest point at the level of 4,929.56. This study used the event study with the windows period for 11 days, which was five days before the announcement, the day of the announcement, and five days after the announcement. This type of research was a quantitative research using secondary data of the stock daily data obtained from the official website of the Indonesia Stock Exchange at www.idx.co.id and also some other sites that support such as Yahoo Finance. Sampling techniques used were purposive sampling and as many as 44 companies that meet data completeness criteria. The data analysis technique used was a non-parametric t-test using the Wilcoxon Signed-Rank test. The results of this study show that there is a difference in Average Abnormal Return in the period $t-5 \& t+5, t-4 \& t+4, t-2 \& t+2$, and $t-1 \& t+1$. The Average Trading Volume Activity indicates there is no significant difference in all periods of observation between before and after the announcement. Meanwhile, the Bid-Ask Spread shows a significant difference before and after the announcement in all periods for 11 days of observation.
\end{abstract}

Keywords: abnormal return, bid-ask spread, COVID-19, trading volume activity.

\section{INTRODUCTION}

An outspoken world society with an outbreak of disease originated from Wuhan city, Hubei Province, China, known as the outbreak of COVID-19 (Coronavirus disease 2019) since its emergence at the end of December 2019. This Virus has infected millions of people in the world and sparked economic chaos globally. Data from the Worldometer shows as of March 2, 2020, there are 3.061 people killed, 2.912 occurring in mainland China, while more than 100 cases of death occur in other countries (Worldometer, 2020). This case has also been reported in more than 60 different countries, including Indonesia. President of Indonesia, Joko Widodo, confirmed the first victim of positive COVID-19 in Indonesia on March 2, 2020, a mother (64 years) and a child (31 years) from Depok, West Java (CNBC Indonesia, 2020).

On March 11, 2020, the World Health Organization (WHO) has officially stated that COVID-19 increased its status to a global pandemic (WHO, 2020). Pandemic is a widespread disease outbreak worldwide (Noya, 2018). The director-general of WHO, Tedros Adhanom Ghebrejesus, mentions the number of cases outside of China has increased 13 times in the last 
two weeks. The WHO announcement was submitted after a death-rate report in Italy, which reached $6 \%$ of patients contracted to COVID-19. At the same time, the globally mortality rate average caused by Coronavirus is 3,6\% (WHO, 2020).

The announcement of COVID-19 as a global pandemic also affects the whole capital market in Indonesia. It is evidenced by the first session of trading on March 12, 2020, the IDX had touched its lowest point at the level of 4.929,56 (Ramli, 2020). The total in this week, the Indonesia Stock Exchange dropped $10,75 \%$ and became the worst weekly performance since October 2008 (Pransuamitra, 2020). Trading at IDX should even undergo a 30-minute trade halt in the week due to a decline of more than $5 \%$. By the policy of the Financial Services Authority (OJK), Stock Exchange trading will be discontinued for 30 minutes if the $\mathrm{JCl}$ plummeted $5 \%$ or more, as a step anticipating in reducing the sharp fluctuations in the capital market (Pransuamitra, 2020).

The information has a vital role in the capital market. It is because the price is a reflection of all relevant information (Efficient Market Hypothesis) (Fama, Cochrane, \& Moskowitz, 2017). In making investment decisions, investors use information such as information relating to fundamental conditions of the company such as financial statements and corporate action announcements as well as macroeconomic factors such as the level of industrial growth, inflation rate, and interest rate (Utama, 2012). However, it is undeniable that non-economic events can impact the capital market.

A study was conducted to investigate the capital market reaction to an event called event study (Suganda, 2018). If the event contains information, then it is indicated by the price change of the relevant securities. This reaction can be measured by using an abnormal return (AR) (Hartono, 2017). Therefore, it can be said that an announcement that has information content will give AR to the market. Conversely, that does not contain information will not provide AR to the market. Getting a return on investment is one of the investor's goals in investing in stocks, so it is necessary to do more research on stock price reactions, as reflected from Abnormal Return (AR). Earlier research using AR as a capital market reaction was conducted by Kim, et al. (2020), Rofiki, et al. (2018), as well as Chen et al. (2007).

Besides to using an abnormal return, the capital market reaction can also be seen through the parameters of movement of trading activity on the market (Trading Volume Activity or TVA), where the investor assesses an event containing information then the event will result in trading decisions on the normal trading decisions (Tandelilin, 2010). In case, after an event resulting in a stock trading volume increases, then the information issued is positive. On the other hand, if the trading volume decreases, then the information published is negative. Active stock trading can increase trading volumes and show that the shares are favored by investors (Subroto, 2014). The presence of rapidly traded stocks would instruct the stocks to be more liquid. Investors will maximize profits and minimize losses by selling or buying a particular stock, so it is necessary to do more research on the reaction of stock trading activity, as reflected from the Trading Volume Activity (TVA). Research to examine TVA's reaction was conducted by Imelda et al. (2014), Putri et al. (2020), as well as Rofiki et al. (2018).

The capital market reaction to information can also be seen through the bid-ask spread. The bid price is the purchase price, while the ask price is the selling price (Saham Gain, 2016). Bid and ask show the process of a transaction between buyers and sellers in the stock market. The difference between the bid and ask price distances is called the Bid-Ask Spread. According to Ong (2016), when the bid-ask spreads are too wide, it indicates that stocks become less actively traded or stocks are not liquid. This level of liquidity is a factor that will need to be considered by investors to choose stocks. If an investor buys a stock that is not liquid, then the investor will encounter difficulties when they want to resell the stock to the market due to a lack of interest in the stock (Ong, 2016). Similarly, a stock will be more liquid indicated by the bid-ask spreads narrower. It shows that the shares are in much demand by investors. The research on bid-ask spreads for 
measuring capital market reactions was conducted by Anwar \& Asandimitra (2014), Melati et al. (2015), and Febrianti (2014).

The research objectives to get empirical evidence of the difference Average Abnormal Return (AAR), Average Trading Volume Activity (ATVA), Bid-Ask Spread before and after the announcement of COVID-19 as a global pandemic at the LQ45 Index. The research aims to obtain empirical evidence of market reactions (abnormal return, TVA, and bid-ask spreads) on the announcement of the COVID-19 by the WHO as the global pandemic because based on the previous descriptions, non-economic events also affect the capital market.

\section{LITERATURE REVIEW AND HYPOTHESIS DEVELOPMENT}

\section{Capital Market}

Republic of Indonesia Law Number 8, the year 1995, defines the capital market as the activities concerned with public offering and securities trading, public companies relating to the securities published, as well as professional institutions relating to the securities (OJK, 2020). The capital market can be defined as a means of funding for companies, governments, and a method of investing in fund owners. Capital markets facilitate various facilities and infrastructures of buying and selling activities and other related activities (Fajar, 2019). Capital markets provide a source of financing for a more extended period, invested as capital to create and expand employment that will increase the volume of profitable and healthy economic activity (Nasarudin et al., 2014).

Sina (2016) mentions that a critical breakthrough in the development of the company's financial theory was the establishment of an efficient market hypothesis by Fama in the year 1970. A market is known to be efficient if no one, both individual investor and institutional investor, will be able to obtain an abnormal return for an extended period using existing trading strategies (Sina, 2016). It shows that the prices formed in the market are a reflection of all available information. If the market reacts quickly and accurately to achieve a new balance price that fully reflects the available information, then this market conditions are called the market efficiently (Hartono, 2017).

Event Study

According to Tandelilin (2010), the event study was a study that observed the impact of the announcement of information on the securities price. This event study relates to how quickly information entered into the market can be reflected in the stock price. While Hartono (2017) mentions that the event study is a study that learns the market reaction to an event whose information is published as an announcement. Meanwhile, according to Suganda (2018), the event study is a study conducted empirically to analyze the impact of events on the capital market of a country. In other words, the study was conducted to investigate the capital market reaction to an event.

The purpose of the event study, as mentioned by Suganda (2018), particularly in the testing of market efficiency, was used to test the market efficiency of semi-strong forms. Besides, Hartono (2017) mentions that the event study can also be used to test the information content of an event or announcement. If an event or announcement contains information, then it is expected that the market will react at the time the market receives the announcement. Market reactions are indicated by the change in the price of securities. This reaction is usually measured using an abnormal return concept. Testing the information content only tests the response of the market, but does not examine how fast the market reacts.

Although the event study has a wide range, lately, it is widely used in events outside of economic issues. Some issues beyond the economic problems that have been researched include the political issue of the election event of DKI Jakarta governor round II by Rofiki et al. (2018); 
political issues about the 2019 presidential election event by Putri et al. (2020); health issues by Kim, et al (2020), and health issues about the SARS outbreak against the performance of the hotel's stake in Taiwan by Chen et al. (2007). Indications of more research based on event studies that take the link between changing the price of stocks with various events or information that is not directly related to economic activity show the more integrated role of the capital market in the social life of the world community.

\section{COVID-19}

At the end of December 2019, the world was deposed with a new virus, the new Coronavirus (SARS-CoV-2), and the disease is called Coronavirus disease 2019 (COVID-19). It is known that the origin of this virus originated in Wuhan, China, which was discovered at the end of December 2019. Epidemiological data shows that $66 \%$ of patients associated with one seafood market or live market in Wuhan, Hubei province, China (Huang, et al., 2020). On February 11, 2020, WHO gave the disease its name to Coronavirus Disease 2019 (COVID-19).

As of March 2, 2020, 3,061 people were killed, 2,912 occurred in mainland China while more than 100 cases of death occurred in other countries (Worldometer, 2020). The case has also been reported in more than 60 different countries, including Indonesia. President of Indonesia, Joko Widodo, confirmed the first victim of positive COVID-19 in Indonesia on March 2, 2020, namely a mother and a child from Depok, West Java, respectively, 64 years and 31 years old. To face the COVID-19, Jokowi said that the government had prepared 100 referral hospitals in the country (CNBC Indonesia, 2020).

On March 11, 2020, the WHO has officially declared the COVID-19 as a global pandemic (WHO, 2020). Pandemic is the name of an infectious disease that spreads in the broader area, even almost all over the world (Noya, 2018). With the setup COVID-19 as a global pandemic, the world community should be more vigilant by complying with the health protocols established by the government. This COVID-19 affects not only health but also affects many areas such as financial areas which becomes worse.

Coronavirus is an RNA virus-positive, capsule, and not segmented (Yuliana, 2020). Coronavirus is a zoonotic virus that is transmitted from animal to human (Juliana, 2020). Many wild animals can carry pathogens and act as vectors for certain infectious diseases. A bats, bamboo rats, camels, and civet are the hosts commonly found for Coronavirus (Perhimpunan Dokter Paru Indonesia, 2020). Coronavirus in the bat is the leading source for the incidence of Severe Acute Respiratory Syndrome (SARS) and Middle East Respiratory Syndrome (MERS) (Perhimpunan Dokter Paru Indonesia, 2020).

In general, Coronavirus flows from animals to humans and from humans to humans through the transmission of contacts, the transfer of droplets, the route of feces, and oral (Wang, Qiang, \& Ke, 2020). Based on the invention, seven types of Coronavirus can infect humans today, one of them is a new Coronavirus, which is the cause of the extraordinary incident in Wuhan, namely Coronavirus Disease 2019 (COVID-19) (Perhimpunan Dokter Paru Indonesia, 2020). People with weak immune systems such as parents, pregnant women, and other conditions, the disease can be progressively faster and more severe.

According to the Perhimpunan Dokter Paru Indonesia (2020), COVID-19 infections may cause mild, moderate, or severe symptoms. The main clinical symptoms are fever (temperature $>38^{\circ} \mathrm{C}$ ), cough, and difficulty breathing. Besides, it can be followed by tightness, fatigue, myalgia, gastrointestinal symptoms such as diarrhea, and other airway symptoms. Half of the patients arise shortness in one week. In some patients, symptoms appear mild, not even followed by fever.

How to spread multiple viruses or pathogens can be through close contact, an environment or virus-contaminated objects, airway droplet, and airborne particles (through the 
skin, blood, or blood fluids) (Perhimpunan Dokter Paru Indonesia, 2020). The best way to prevent infection is to avoid exposure to the virus, causing the disease.

\section{Abnormal Return (AR)}

The market reaction due to an event usually observes the change in the price of shares measured by abnormal returns. As mentioned in Hartono (2017) that if used abnormal return, it can be said that an announcement that has information content will give an abnormal return to the market. Conversely, that does not contain information that does not give abnormal returns to the market. Abnormal return, according to Hartono (2017), is the difference between actual return and the expected profit (expected return). This abnormal return or excess return is the excess of the actual return occurring against the normal return.

Chen et al. (2007) conducted a study on the impact of the SARS outbreak against the hotel's stock performance in Taiwan. In this study, they found that the market reaction to the publication of severe acute respiratory syndrome (SARS) gave a decrease in yield to various industrial sectors in the Taiwan capital market. The Cumulative Abnormal Return showed insignificant in all industries at ten days before the event. However, after ten days of events show there is a significant negative cumulative AR. Putri, et al. (2020) analyzed the capital market reaction of the LQ45 Index against the 2019 presidential elections. This study analyzes AR and TVA against political events in Indonesia with two research periods. The results showed no significant differences in AR before and after elections, but there were significant differences before and after the announcement of election results. Kim, et al. (2020) analyzed the effects of epidemic disease outbreaks on financial performance of restaurants. The result of this study showed that the general impact of the four epidemic disease outbreaks with nine events (Diseases total) was significantly negative AR over the event window

H1 : There is differences in average abnormal returns on the LQ45 Index before and after the COVID-19 announcement as a global pandemic.

Trading Volume Activity (TVA)

According to Tandelilin (2010), Trading Volume Activity (TVA) is the ratio between the number of shares traded at a specific time to the number of shares in circulation at a given time. Certain information or events can trigger the movement of stocks in the capital markets that will affect the supply and demand of stocks. TVA is a sale of every transaction occurring on stock exchanges at a specific time for a particular stock and is one of the factors that also affect the movement of stocks (Suganda, 2018).

Imelda et al. (2014) conducted research on abnormal returns and trading volume activity in the Indonesian Stock Market in Relation to the Presidential Elections., the trading volume activities of the Indonesian's sectoral stock market before and after the elections were statistically the same. Based on Melati et al. (2015) there is a significant difference to the average TVA before and after the event. Rofiki, et al. (2018) examined the Indonesian capital market reaction the variable trading volume activity did not find any significant differences in trading volumes before and after. Putri, et al. (2020) The TVA shows there are differences before and after the elections. But, there is no difference between TVA before and after.

$\mathrm{H} 2$ : There are differences in average trading activity volume on the LQ45 Index before and after the COVID-19 announcement as a global pandemic.

Bid-Ask Spread (BAS) 
Bid-ask spread is the percentage of the difference between the bid price and the ask price. Bid prices are the highest price where market participants are willing to buy stocks, while the ask price is the lowest price in which the participants are ready to sell the stock. A bid-ask spread that is too high will result in the stock being less actively traded. At the same time, low bid-ask spreads will result in the stocks becoming more actively sold. Therefore, market participants will try to determine the optimal bid-ask spread level, which is the bid-ask spread rate that can generate the expected profit but still make the shares become actively traded.

According to Fatikhah and Puryandani (2020), the increase in bid-ask spreads can be influenced due to factors or phenomena in the stock market such as stock price volatility, the January Effect phenomenon, and Window Dressing, as well as bad news issues or good news. Decreased bid-ask spread of LQ45 stocks often occurs at the end of the year as investors tend to take out shares to gain capital gains and reduce the tax burden of these stocks (Fatikhah \& Puryandani, 2020). \

Febrianti (2014) researched the bid-ask spread before and after the stock split announcement. It can be concluded that there is no significant difference between the bid-ask spread before and after the stock split announcement. Anwar and Asandimitra (2014) analyzed the bid-ask spread test shows there are differences in bid-ask spreads on $t-4, t-2, t-1, t+1, t+2$, and $t+4$ on companies that do split stock. It causes information to spread evenly between market actors and lower the cost of information asymmetry so that bid-ask spreads also decrease. Melati et al. (2015) researched the impact of presidential. Abnormal return, TVA, and bid-ask spreads on the LQ45 Index. The results showed that there was no difference in average abnormal return, and significant bid-ask spreads before and after the event.

H3 : There are differences in bid-ask spreads on the LQ45 Index before and after the COVID-19 announcement as a global pandemic.

\section{LQ45 Index}

In the first Indonesian capital market was still classified as a capital market with a thin transaction, which is the capital market mostly less-actively traded. The $\mathrm{JCl}$ covers all listed stocks (which are mostly less actively traded) are considered less precise as an indicator of capital market activities. Therefore, on February 24, 1997, it was introduced as another alternative index, the Liquid-45 Index (ILQ-45) (Hartono, 2017).

The LQ45 Index is an index that measures the price performance of 45 stocks that have high liquidity and large market capitalization and are backed by good corporate fundamentals (IDX, 2020). The considerations underlying the stock selection entered at the LQ- 45 Index are the liquidity and market capitalization with the following criteria (Hartono, 2017):

(1) Over the past 12 months, the average stock deal was in the most significant order of 60 in the regular market. (2) Over the past 12 months, the average market capitalization rate was entered in the largest 60 sequences in regular markets. (3) Has been recorded at IDX at least three months. A total of 45 shares are adjusted every six months, namely every early February and August. Thus, the stocks on the list will always change.

\section{RESEARCH METHODOLOGY}

\section{Type of Research}

The type of research used is an event study, which is research studying the market reaction to an event whose information is published as an announcement (Hartono, 2017). Research with event studies focuses on testing the content of information on an event. The events tested were the announcement of COVID-19 as a global pandemic delivered by the WHO on Wednesday night, March 11, 2020 (WHO, 2020). 
This research only uses the observation period or does not use the estimated period based on the Market Adjusted Model used to calculate the expected return. This model used the market index return at that time to estimate the return of a security, so no need to use the estimated period to form the estimation model, because the estimated securities return is equal to the return of the market index (Hartono, 2017).

Population, Sample, and Windows Period

In this research, the population used are all companies registered on the Indonesia Stock Exchange (IDX). The samples used in this study were registered companies in LQ45 from the period of February 2020. In this study, the sampling techniques used were the purposive sampling method, which is a sampling technique with specific criteria (Sugiyono, 2017). The criteria are:

(a) Companies listed on the Indonesia Stock Exchange and the LQ45 Index since February 2020. (b) Companies that do not perform other corporate actions during the observation period (event window), such as stock split, warrant, dividend announcement, right issue, additional shares, stock buyback, and merger. (c) Companies have the complete data for research.

Based on the criteria above, the company acquired a qualified list of 44 companies.In the present study, researcher used a windows period five days before and five days after the COVID19 announcement as a global pandemic. For determining the expected return, the researcher using a market-adjusted model where the return expectations of the market return data when the event occured. Here is an example of the picture windows and the estimation period:

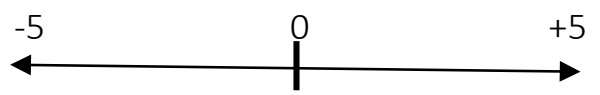

Figure 2. Windows Period

Place and Time Research

This research was conducted on the company that has been listed on the Indonesia Stock Exchange (IDX), which was entered in the LQ45 Index since February 2020. Data is obtained through the official website of the Indonesia Stock Exchange at www.idx.co.id and some sites that support such as www.yahoofinance.com. The research began in March 2020.

Operational Definitions of Research Variable

Abnormal Return

This abnormal return or excess return is the excess of the actual return occurring against normal return. Normal return is a return expectation (the return expected by the investor). Thus, an abnormal return is a difference between the actual return rate and the expected return level (Hartono, 2017).

The steps in looking for abnormal return shares, as follows (Hartono, 2017):

Calculating the actual return, i.e.:

$$
R_{i, t}=\frac{P_{i, t}-P_{i, t-1}}{P_{i, t-1}}
$$

Information:

$\mathrm{R}_{\mathrm{i}, \mathrm{t}} \quad=$ Actual return of shares $\mathrm{i}$ in period $\mathrm{t}$

$\mathrm{P}_{\mathrm{i}, \mathrm{t}} \quad=$ Closing stock price of the company $\mathrm{i}$ in period $\mathrm{t}$

$\mathrm{P}_{\mathrm{i}, \mathrm{t}-1}=$ Closing stock price of the company $\mathrm{i}$ in period $\mathrm{t}-1$

Calculating the daily expected return of the stock, using a market-adjusted model where the estimated period is not required because the stock return equals the approximate market index at that time. The expected return can be obtained by the following formula:

$$
E\left(R_{i t}\right)=R m_{t}
$$


Information:

$E\left(R_{i t}\right) \quad=$ Expected return of security $i$ in the period $t$

$\mathrm{R}_{\mathrm{mt}} \quad=$ Market return in the period $\mathrm{t}$, calculated with the formula:

$$
R_{m t}=\frac{I H S G_{t}-I H S G_{t-1}}{I H S G_{t-1}}
$$

Information:

$\mathrm{R}_{\mathrm{mt}} \quad=$ Market return in the period $\mathrm{t}$

IHSG $_{t} \quad=$ The daily IHSG in the period $t$

$\mathrm{IHSG}_{\mathrm{t}-1}=$ The daily IHSG in the period $\mathrm{t}-1$

Calculating abnormal return which is the difference between actual return and expected return, i.e.:

$$
A R_{i t}=R_{i t}-E\left(R_{i t}\right)
$$

Information:

ARit $=$ Abnormal return of securities $\mathrm{i}$ in the period $\mathrm{t}$

Rit $\quad=$ Actual return of securities $i$ in the period $t$

$E$ (Rit) = Expected return of securities $i$ in the period $t$

Testing the absence of abnormal returns is not done for each of the securities. However, it is carried out in aggregate by testing the average abnormal return of the entire securities on a crosssection basis for each day in the period. Here's how to calculate an average abnormal return (AAR) for all stocks per day during an event period, i.e.:

$$
A A R_{t}=\frac{\sum A R_{i t}}{k}
$$

Information:

$\begin{array}{ll}\text { AARt } & =\text { Average abnormal return on day } t \\ \text { ARit } & =\text { Abnormal return of securities } i \text { on day } t \\ k & =\text { The number of securities affected by the event }\end{array}$

Trading Volume Activity

Trading Volume Activity (TVA) shows stock trading activity and reflects how active and liquid a stock is traded in the capital market. TVA calculations are done by comparing the number of shares of the company traded with the overall number of outstanding shares of the company during the research period. Here are the steps calculating the TVA is as follows:

Counting the TVA of each stock during the research period:

$$
T V A_{i, t}=\frac{\text { Company } i \text { shares traded at time } t}{\text { Company } i \text { shares outstanding at time } t}
$$

(Husnan, 2015)

Calculating the average TVA (ATVA) of the entire stock per day during an event period (Husnan, 2015), namely:

$$
A T V A_{t}=\frac{\Sigma T V A_{i t}}{n}
$$

Information:

ATVAt = Average trading volume activity on day $t$

TVA $_{\text {it }} \quad=$ Trading volume activity of securities $\mathrm{i}$ on day $\mathrm{t}$ 
$\mathrm{n} \quad=$ Total securities

\section{Bid-Ask Spread}

Bid-Ask spreads are the percentage of the difference between the bid price and ask price. Bid prices are the highest price where market participants are willing to buy stocks, while the ask price is the lowest price where the participants are ready to sell the stock.

Here are the steps to calculate the bid-ask spread according to Howe and Lin (1992) in Melati et al. 2015 are as follows:

Calculating bid-ask spreads for each security during the research period:

$$
\text { Bid Ask Spread }=\frac{\text { Ask }_{i t}-B_{i d_{i t}}}{\left(\text { Ask }_{i t}+B i d_{i t}\right) / 2}
$$

Information:

Askit : The lowest selling price that causes investors to agree to sell stock company $i$ on day $\mathrm{t}$

Bid $d_{i t} \quad$ : The highest price that led investors agreed to buy shares of a company $i$ on day $t$

Calculates the average bid-ask spread of all stocks per day during the event period, i.e.:

$$
\text { Average Bid Ask Spread }_{t}=\frac{\sum{\text { Bid Ask } \text { Spread }_{i t}}_{n}}{n}
$$

Information:

$\mathrm{n}=$ Total of securities

Data Collection Method

The data used in this research is secondary data originating from the official website of the Indonesia Stock Exchange at www.idx.co.id and also some sites that support such www.yahoofinance.com. Secondary data is also derived from articles, journals, and various other literature. The data collected in this study are as follows:

(a) The daily stock price of March 2020. The stock price data used is the closing price because the price has been determined by the market. This daily data is used because it has a high level of sensitivity in responding to market reactions. (b) The stock daily of bid price and ask price at the observation period.

(c)The daily IDX data for the observation period. (d) The daily data of trading volumes during the observation period. (e) The data on the number of outstanding shares of the sample company in a certain period.

\section{RESEARCH RESULT}

Descriptive Statistic

The descriptive statistical analysis was conducted to determine the picture of a fundamental sample, such as the average value of each sample before and after the COVID-19 announcement, maximum value, and minimum value. Descriptive statistics include the following table, which can explain the abnormal return research (AAR) data, average stock trading volume (ATVA), and bid-ask spreads during the observation period in this study.

Table 1. Descriptive Statistic AAR

\begin{tabular}{|c|c|c|c|}
\hline AAR & Before & After & Information \\
\hline Maximum Value & 0,0254 & 0,0219 & Down \\
\hline Minimum Value & $-0,0304$ & $-0,0442$ & Down \\
\hline
\end{tabular}




\begin{tabular}{|}
\begin{tabular}{|c|c|c|c|}
\hline Average & $-0,0057$ & $-0,0180$ & Down \\
\hline
\end{tabular} \\
Source: Data processing results (2020)
\end{tabular}

From table 1 , abnormal return indicates that 44 companies have a maximum value before the announcement event is 0,0254 and after the announcement is 0,0219. While the minimum value before the announcement event is $-0,0304$ and after the announcement is $-0,0442$. Then the averages abnormal return also decreased, which is before the announcement is $-0,0057$ and after the announcement is $-0,0180$. From 44 companies that become samples, 12 companies experienced an increase in abnormal returns. At the same time, 32 other companies experienced a decrease in abnormal returns. The decrease in abnormal returns after an announcement indicates that the market has reacted to the COVID-19 as the global pandemic.

Table 2. Descriptive Statistic ATVA

\begin{tabular}{|c|c|c|c|}
\hline ATVA & Before & After & Information \\
\hline Maximum Value & 0,0067 & 0,0056 & Down \\
\hline Minimum Value & 0,0004 & 0,0003 & Down \\
\hline Average & 0,001701 & 0,00168 & Down \\
\hline
\end{tabular}

Source: Data processing results (2020)

From table 2 , the results of ATVA indicate that the data has a maximum value before the announcement is 0,0067 and after the announcement is 0,0056. Meanwhile, the minimum TVA before the announcement event amounted to 0,0004 and after the announcement is 0,0003. Then the average TVA is decreasing, before the announcement is 0,001701 and after the announcement is 0,00168 . There are 19 companies experienced an increase in TVA. At the same time, 25 other companies are decreasing in TVA. The decrease in the TVA after the announcement event indicated that the market reacts to the COVID-19 announcement event as the global pandemic but still needs to be viewed statistically.

Table 3. Descriptive Statistic Bid-Ask Spread

\begin{tabular}{|c|c|c|c|}
\hline BAS & Before & After & Information \\
\hline Maximum Value & 0,0123 & 1,6009 & Rise \\
\hline Minimum Value & 0,0014 & 0,0029 & Rise \\
\hline Average & 0,0047 & 0,9224 & Rise \\
\hline
\end{tabular}

Source: Data processing results (2020)

From table 4, the result of the bid-ask spread showed that the data had a maximum value before the announcement is 0,0123 and after the announcement is 1,6009. Meanwhile, the minimum TVA before the announcement event is 0,0014 and after the announcement is 0,0029. From the table above, the average bid-ask spread before the announcement is 0,0047 , and after the announcement is 0,9224 . There are 42 companies had experienced an increasing the bid-ask spreads. At the same time, the other 2 companies are decreasing in bid-ask spreads. The increase in bid-ask spreads after an announcement event indicates that the market reacts to the COVID19 announcement as the global pandemic, but it remains to be viewed statistically.

Normality Test

Based on the AAR normality test results, it is known that the AAR before the event on t$5, t-4 t-3, t-1$, and after the event on $t+1$ is a normally distributed. It is indicated by the value of 
asymptotic significance above 0,05. However, in other periods before and after events have abnormal data distribution, it is indicated with an asymptotic value significance below 0,05 . Thus, the next testing is using non-parametric statistical tests due to the data is not normally distributed.

Based on the ATVA normality test results, it is known that the average trading activity volume before and after the announcement is obtained asymptotic value significance smaller than 0,05 . It indicates that trading activity volume distribution is abnormal, so for the next testing uses non-parametric statistical tests.

Based on the bid-ask spread normality test result, it is known that the bid-ask spread before the event on $\mathrm{t}-1$ is normal distribution, it is indicated by the value of asymptotic significance above 0,05 . However, in other periods before and after the event has an abnormal data distribution, it is indicated with an asymptotic value significance below 0,05. Thus, subsequent testing using non-parametric statistical tests is due to data having abnormal distribution.

Hypothesis Test

$\mathrm{H} 1$ hypothesis testing aims to determine the difference in AAR on the LQ45 Index before and after the COVID-19. Then the $\mathrm{H} 2$ hypothesis test aims to determine the difference in the ATVA on the LQ45 Index before and after the COVID-19 announcement as a global pandemic. Meanwhile, $\mathrm{H} 3$ hypothesis testing aims to determine the difference in bid-ask spreads on the LQ45 Index before and after the COVID-19 announcement.

Table 4. Hypothesis Test AAR

\begin{tabular}{|c|c|c|c|}
\hline Period & z-count & $\begin{array}{c}\text { Asymp. Sig. } \\
(2 \text {-tailed })\end{array}$ & Meaning \\
\hline AAR t+5 - AAR t-5 & $-4,890$ & $0,000^{*}$ & Significant \\
\hline AAR t+4 - AAR t-4 & $-3,583$ & $0,000^{*}$ & Significant \\
\hline AAR t+3 - AAR t-3 & $-1,015$ & 0,310 & Not Significant \\
\hline AAR t+2 - AAR t-2 & $-3,536$ & $0,000^{*}$ & Significant \\
\hline AAR t+1 - AAR t-1 & $-4,260$ & $0,000^{*}$ & Significant \\
\hline
\end{tabular}

Source: Data Processing Results

*Significant on $\alpha=0,05$

Based on the test results in table 4, it can be known that there are different AAR differences in the period $t-5$ and $t+5$. It is evidenced by the value of Asymp. Sig. (2-tailed) of the Wilcoxon signed-rank test is 0,000, which is smaller than the research significance level of 0,05. For a period of $\mathrm{t}-4$ and $\mathrm{t}+4$, the value of Asymp. Sig. (2-tailed) produced amounting to 0,000. The results indicate that at period $t-4$ and $t+4$ days after the announcement, there is a difference in the average abnormal return evidenced by the existence of Asymp. Sig. (2-tailed) smaller than the significance level of research. Meanwhile, at $t-3$ and $t+3$, the value of Asymp. Sig. (2-tailed) produced amounting to 0,310 . Because the value above 0,05 means there is no significant difference in abnormal return at $\mathrm{t}-3$ and $\mathrm{t}+3$. Furthermore, in $\mathrm{t}-2$ and $\mathrm{t}+2$, there is a difference in abnormal return significantly. It is evidenced by the value of Asymp. Sig. (2-tailed) amounted to 0,000 . Besides, there is also a difference in average abnormal return in the period $t-1$ and $t+1$. These results can be evidenced by the value of Asymp. Sig. (2-tailed) 0,000, that is smaller than the level of research significance.

Table 5. Hypothesis Test ATVA

\begin{tabular}{|l|l|l|l|}
\hline Period & z-count & $\begin{array}{c}\text { Asymp. } \\
\text { Sig. (2- } \\
\text { tailed) }\end{array}$ & Meaning \\
\hline
\end{tabular}




\begin{tabular}{|l|l|l|l|}
\hline ATVA t+5 - ATVA t-5 & $-1,132$ & 0,258 & Not Significant \\
\hline ATVA t+4 - ATVA t-4 & $-1,821$ & 0,069 & Not Significant \\
\hline ATVA t+3 - ATVA t-3 & $-1,365$ & 0,172 & Not Significant \\
\hline ATVA t+2 - ATVA t-2 & $-1,739$ & 0,082 & Not Significant \\
\hline ATVA t+1 - ATVA t-1 & $-1,342$ & 0,180 & Not Significant \\
\hline
\end{tabular}

Source: Data Processing Results

Based on the test results in table 5 , it is known that there is no average difference of TVA in the period $t-5$ and $t+5$. Meanwhile, for a period of $t-4$ and $t+4$, there is also no significant difference in average TVA. In the period $t-3$ and $t+3$, there is not also a significant average TVA. The Wilcoxon test result of a signed-rank test shows that in the period $t-2$ and $t+2$, there is no difference in ATVA at a significance level of $5 \%$. Meanwhile, for a period of $t-1$ and $t+1$ resulted in the asymptotic significance of 0,180 . It indicates that there is no difference in ATVA in the period $\mathrm{t}-1$ and $\mathrm{t}+1$.

Table 6. Hypothesis Test Bid-Ask Spread

\begin{tabular}{|c|c|c|c|}
\hline Period & z-count & $\begin{array}{c}\text { Asymp. } \\
\text { Sig. (2- } \\
\text { tailed) }\end{array}$ & Meaning \\
\hline BidAsk $t+5$ - BidAsk t-5 & $-4,878$ & $0,000^{*}$ & Significant \\
\hline BidAsk $t+4$ - BidAsk $t-4$ & $-5,660$ & $0,000^{*}$ & Significant \\
\hline BidAsk $t+3$ - BidAsk t-3 & $-5,532$ & $0,000^{*}$ & Significant \\
\hline BidAsk $t+2$ - BidAsk t-2 & $-2,089$ & $0,037^{*}$ & Significant \\
\hline BidAsk $t+1$ - BidAsk $t-1$ & $-2,206$ & $0,027^{*}$ & Significant \\
\hline
\end{tabular}

Source: Data Processing Results

*Significant on $\alpha=0,05$

Based on table 6 , it can be known that there is a difference in the average bid-ask spread at the $t-5$ and $t+5$ period. Meanwhile, for a period of $t-4$ and $t+4$, there is also a difference in average bid-ask spreads are significant. In the period $t-3$ and $t+3$, there is also a significant bidask average spread. In the period $t-2$ and $t+2$, there are significant bid-ask spreads that are indicated by the results of the significance asymptotic test is 0,037 . Meanwhile, for a period of $t$ 1 and $t+1$ results in the asymptotic significance is 0,027 . It indicates that there is a significant difference in the bid-ask spread in the period $t-1$ and $t+1$. The Wilcoxon signed-rank test on the bid-ask spread indicates that for all periods before and after the announcement resulted in asymptotic significance greater than 0,05 . It indicates that there is a significant bid-ask average on all for 11 days of observation.

\section{Discussion}

Based on the hypothesis tests that have been conducted, the following is a discussion of the test results:

H1 Discussion

Based on the $\mathrm{H} 1$ hypothesis testing results, the market reaction measured by an average abnormal return can be seen in the following table:

Table 11. Market Reaction Measured by AAR

\begin{tabular}{|c|c|c|c|c|c|}
\hline Periode & AAR Before & AAR After & Significance & Meaning & Market Reaction \\
\hline $\mathrm{t}-5$ and $\mathrm{t}+5$ & 0,0100 & $-0,0228$ & Yes & Down & Negatif \\
\hline
\end{tabular}


Soedirman Accounting Review, December 2020, Vol. 6 No. 02 Tahun 2020, Hal 120 -137

\begin{tabular}{|c|c|c|c|c|c|}
\hline$t-4$ and $t+4$ & $-0,0058$ & $-0,0327$ & Yes & Down & Negatif \\
\hline$t-3$ and $t+3$ & $-0,0095$ & $-0,0040$ & No & - & - \\
\hline$t-2$ and $t+2$ & $-0,0274$ & 0,0013 & Yes & Rise & Positif \\
\hline$t-1$ and $t+1$ & 0,0042 & $-0,0318$ & Yes & Down & Negatif \\
\hline
\end{tabular}

From table 11, it can be concluded that there are significant negative-value AAR in the t-1 $\& t+1, t-4 \& t+4$ periods, as well as $t-5 \& t+5$. By contrast, there are significant positive-value AAR in the $t-2$ and $t+2$ periods. AAR is significantly negative in the $t-1$ and $t+1$ period comparisons indicating that the COVID-19 outbreak announcement information as a global pandemic was negatively responded by market participants. One factor that affects the market's negative reaction is the investor's concerns when they heard the announcement from the WHO states that the COVID-19 was a global pandemic. Many investors are transferring funds from stock investments to safer investments. It makes the stock market oversupply and eventually corrected. This was evidenced by the decrease of the $\mathrm{JCl}, 2,94 \%$ in trade 1 March 12, 2020, the day after the COVID-19 was announced as a global pandemic (Ramli, 2020). According to the Tandelilin (2010), if the information is deemed good, it will be positively responded by the market that can be seen from the existence of AR around the event. However, if it is considered bad news, it will be negatively responded to the negative value of $A R$.

The significant negative AAR that was occurred in the $t-1$ and $t+1$ periods did not continue, even in the $t-2$ and $t+2$ periods, the AAR was positively valued significantly. The AAR's significant positive value in the $t-2 \& t+2$ periods indicates that there is an increase in the stock price on the exchange floor. The OJK has been issued policies to maintain the sustainability of trading activities in the capital market, one of them is the execution of trading halt for 30 minutes in terms of the rate of 5\% decline, precisely on 12 and 13 March 2020 (OJK, 2020). This policy was successful because it was able to raise the stock price, so the AAR became positive. However, the AAR returned to negative periods in $t-4$ and $t+4$ and $t-5$ with $t+5$. It indicates that the stock price is back down. One factor causing the market reacts negatively because of the inconsistency between the central government and local governments in handling the COVID-19. According to the Indonesian Community Health Expert Association (IAKMI), Hermawan Saputra, said that the government protocol in preventing the spread of Corona viruses is still weak. In addition, statements which is issued by the central government and local governments often overlap and there was an absence of a detailed division of the role of government in Indonesia (Egeham, 2020). Besides, the positive Indonesian patients of COVID-19 had been increased to 172 cases per 17 March 2020 (Thirzano, 2020). It makes investors increasingly worried that caused company's stock price getting down. When the stock price drops, the abnormal return that was earned by the investor is also negative because the investor's realization return is lower than the expected return.

The announcement event of COVID-19 as a global pandemic gives a signal regarding to the bad information on exchange activity or declining stock price movements, which give a risk to investors and their investments. The average difference in abnormal returns occurring in the period before and after the COVID-19 event as a global pandemic proves that the event has useful information content for investors in making investment decisions.

The $\mathrm{H} 1$ hypothesis test results managed to support research from Chen et al. (2007), who researched the impact of the SARS outbreak against the hotel's stock performance in Taiwan. After 10 days of SARS event, indicate there is a significant cumulative Abnormal Return negative. Research conducted by Kim, et al. (2020) examining the effects of epidemic disease outbreaks on financial performance of restaurants showed that the general impact of the four epidemic disease outbreaks with nine events (Diseases total) was significantly negative AR over the event window. Other research conducted by Rofiki et al. (2018) about the reaction of the Indonesian capital 
market from the election event of the governor of DKI Jakarta round II 2017 showed that there is a significant difference in AR period before and after events.

H2 Discussions

The $\mathrm{H} 2$ hypothesis testing results showed that there were no significant differences between ATVA before and after the COVID-19 announcement event as a global pandemic, both on $\mathrm{t}-1 \& \mathrm{t}+1, \mathrm{t}-2 \& \mathrm{t}+2, \mathrm{t}-3 \& \mathrm{t}+3, \mathrm{t}-4 \& \mathrm{t}+4$, or $\mathrm{t}-5 \& \mathrm{t}+5$. The absence of significant average TVA was differences before and after the event, which is indicated that there was no market reaction to the COVID-19 announcement information as a global pandemic. Viewing from the descriptive analysis of TVA, the average TVA showed a decline but statistically not significant. Many investors released their shares by selling it. They worried that the stocks of the companies are unable to survive in the middle of this pandemic, resulting in a drastic share price. Some investors choose to transfer their funds from risky investments to safer investments (Efendi, 2020). It makes the stock market has a surplus of supply so that the stock price was felled. However, the decline in the share price caused many investors buy it, hoping that investors will get a high return when the COVID-19 pandemic is over. It is considered to be an insignificant reason for TVA in the period before and after the announcement of COVID-19. The absence of significant average TVA differences before and after the event indicated that there was no increase or decrease in trading activity on the exchange floor.

Based on companies listed in the LQ45 index, the type of sector most affected by the COVID-19 announcement as a global pandemic as measured by TVA is the retail trade sector with an ATVA decrease is 0,0023 . This indicates that the retail trade sector experienced the most decline in stock trading activity compared to other sectors. Meanwhile, the type of sector that benefited after the announcement as measured by TVA was building construction sector and textile \& garment sector with ATVA is 0,005 . This indicates that the types of building construction and textile and garment sectors experienced the most increase in stock trading activity compared to other sectors.

The results of this research are in line with research conducted by Rofiki et al. (2018), stating that there is no significant difference to TVA before and after the election event of DKI Jakarta round II the year 2017 where TVA after greater than TVA before the event. Then study conducted by Imelda et al. (2014) about Indonesian Stock Market in Relation to the Presidential Elections in 2004, 2009, and 2014, indicating that there is no difference TVA before and after the announcement. But inversely proportional to the research by Putri et al. (2020) about the analysis of the capital market reaction of the LQ45 index to the presidential election of 2019 showed that there is a difference between the before and after elections events.

H3 Discussion

The result of $\mathrm{H} 3$ hypothesis testing showed that there was a significant bid-ask spread on all periods, in $\mathrm{t}-1 \& \mathrm{t}+1, \mathrm{t}-2 \& \mathrm{t}+2, \mathrm{t}-3 \& \mathrm{t}+3, \mathrm{t}-4 \& \mathrm{t}+4$, and $\mathrm{t}-5 \& \mathrm{t}+5$. Based on the $\mathrm{H} 3$ hypothesis testing results, the bid-ask spread difference before and after events in each period can be seen in the following table:

Table 12. Difference Bid-Ask Spreads Before and After Events

\begin{tabular}{|l|l|}
\hline Before Announcement & After Announcement \\
\hline
\end{tabular}




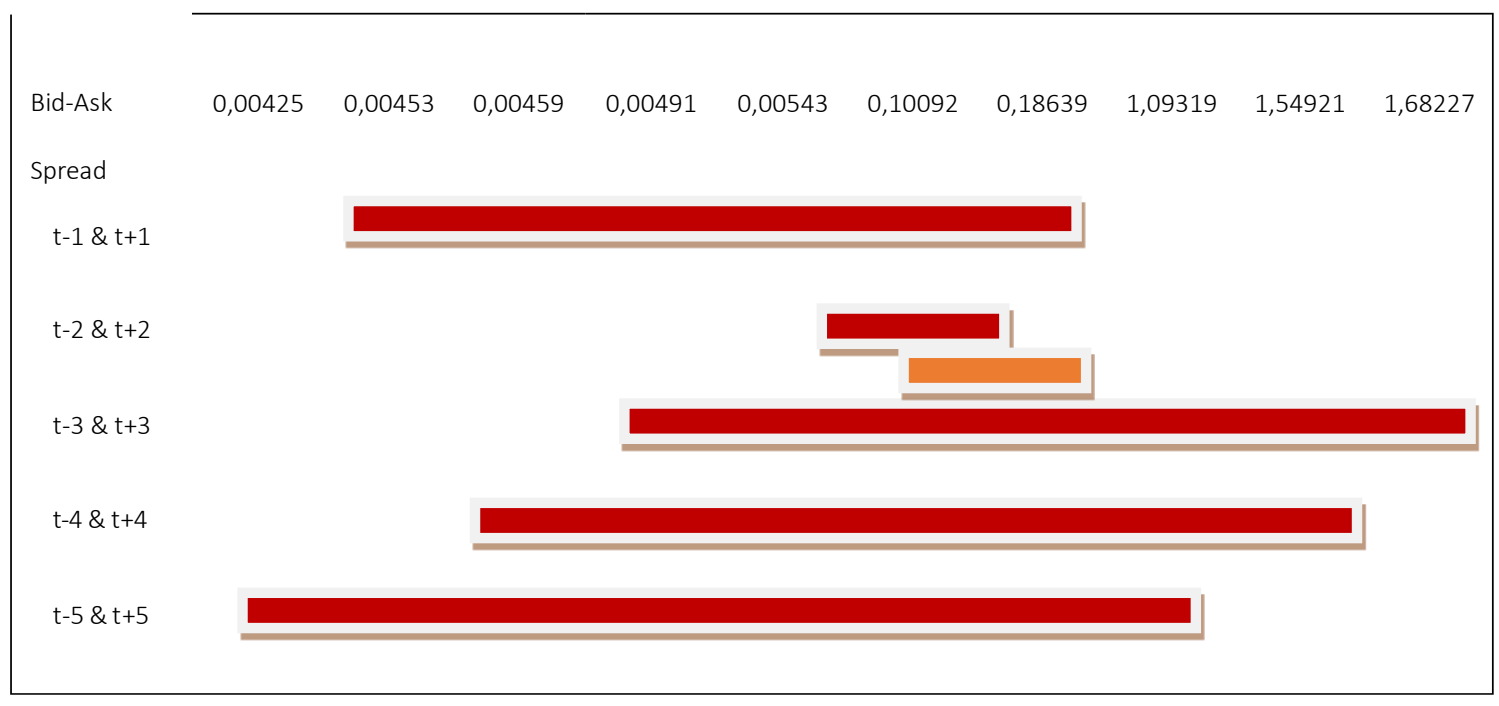

In the table above, it can be seen that the bid-ask spread is narrowed in the $\mathrm{t}-2 \mathrm{\&} \mathrm{t}+2$ period. According to Prasiska and Nuzula (2018), high liquidity is represented by the position of bid-ask spread which becomes lower. This narrowing is due to the interest and demand of investors are increasing toward stock companies that cause the stocks become more liquid. High liquidity stocks mean high levels of activity. This narrowing can also be seen from the positive AAR on $\mathrm{t}-2$ and $\mathrm{t}+2$, which indicates that the share price is also increasing. Bid-ask spreads will be lower when the share price is high (Maulina \& Rusno, 2011). Stock prices in the Indonesian Stock Exchange are highly determined by the power of demand and supply. When the stock demand rises, the share price will tend to increase. While many investors sell their shares, the share price will tend to decrease.

The bid-ask conditions of the narrow spread in the $t-2 \& t+2$ period do not last long time. These conditions can be seen in the expanded spreads in the $t-3 \& t+3, t-4 \& t+4$, and $t-5 \& t+5$ periods. The spread of bid-ask spreads in that period indicates that the interest and demand of investors to the company's shares are decreasing, that cause the stocks become less liquid. It is also reflected in the negative AAR in the $t-3 \& t+3, t-4 \& t+4$, and $t-5 \& t+5$ periods indicating that the stock price are decreasing. According to Andriani (2020), foreign investors booked a net sell action of about Rp2,45 trillion during the week of 16-20 March. The purchase action was recorded to 10,07 billion pieces worth Rp17,51 trillion, at the same time selling foreign investors reached 12,11 billion shares with a value of Rp19,96 trillion. The large number of investors who sell the stocks causes an excessive supply of the stocks which results in a decline in stock prices.

Based on the companies listed in the LQ45 index, the type of sector most affected by the COVID-19 announcement as a global pandemic as measured by Bid-Ask Spread is the retail trade sector with a bid-ask spread increase is 1,59755. This indicates that the retail trade sector is the least liquid company after the announcement of COVID-19 as a global pandemic. Meanwhile, the type of sector that experienced a decrease in Bid-Ask Spread after the announcement was the pharmaceutical sector with Bid-Ask Spread is 0,0016. This indicates that the type of pharmaceutical sector is the most liquid sector when compared to other sectors.

The results of this study supported the research conducted by Anwar \& Asandimitra (2014) with the research results; there are differences of bid-ask spreads $t-4, t-2, t-1, t+1, t+2$, and $t+4$ on companies that do split stock. Meanwhile, research from Melati et al. (2015) shows that there is no significant difference between the bid-ask spread before and after the presidential election event in 2014. Similar research results are also found in research conducted by Febrianti (2014) that there is no significant difference between bid-ask spread before and after the stock split announcement. 


\section{CONCLUSIONS AND SUGGESTION}

Conclusions

Based on the discussion that has been submitted, there can be several conclusions as follows:

There is a significant difference between AAR before the announcement of the COVID-19 by the WHO as the global pandemic, which is in the period $t-5$ and $t+5$, $t-4$ and $t+4, t-2$ and $t+2$, as well as $t-1$ and $t+1$. At the same time, in the period $t-3$ and $t+3$ there is no significant difference between AAR before the announcement of the COVID-19 by the WHO as the global pandemic. The test indicated that the Indonesian capital market reacted to the announcement of the COVID19 as a global pandemic delivered by the WHO.

There is no significant difference at all observation periods between ATVA before and after the announcement of the COVID-19 by the WHO as a global pandemic. Although the ATVA before the event period is higher than after the period, it does not indicate a statistically significant difference. It shows that there is no increase or decrease in the trading activity on the exchange floor.

There is a significant difference between the bid-ask spread before and after the announcement of the COVID-19 as the global pandemic presented by the WHO, in all periods of the 11-day observation. It indicates that the information about the announcement of COVID-19 as a global pandemic may inform investors about the liquidity of a company's shares.

Suggestion

Based on the above conclusions can be given the following suggestions:

Investors are advised to analyze the information before investing in the capital market. Further studies are advised to:

Adding capital market reaction measurements other than AR, TVA, and bid-ask spreads such as security return variability and stock trading frequency.Using an expected return measurement model not only uses the market adjusted model but also uses two other models, namely the market model and the mean adjusted model. Divide the company by company size, company type, or other specific characteristics.

\section{REFERENCES}

Andriani, R. S. (2020). IHSG Tersungkur 14 Persen Lebih Sepanjang 16-20 Maret 2020. Retrieved from Bisnis.com: https://market.bisnis.com/read/20200323/7/1216701/ihsgtersungkur-14-persen-lebih-sepanjang-16-20-maret-2020

Anwar, F., \& Asandimitra, N. (2014). Analisis Perbandingan Abnormal Return, Trading Volume Activity,

dan Bid-Ask Spread Sebelum dan Sesudah Stock Split. Jurnal Bisnis dan Manajemen Vol.

7,

34-44.

Chen, M. H., Jang, S., \& Kim, W. G. (2007). The Impact of The SARS outbreak on Taiwanese Hotel Stock Performance: An event-study approach. Hospitality Management, 200-212.

CNBC Indonesia. (2020). Alert! Pernyataan Lengkap Jokowi Soal 2 Orang Positif Corona. Retrieved from CNBC Indonesia: https://www.cnbcindonesia.com/news/20200302114455-4141660/alert-pernyataan-lengkap-jokowi-soal-2-orang-positif-corona

Efendi, A. (2020). Tips Investasi Saat Pandemi Corona COVID-19. Retrieved from tirto.id: https://tirto.id/tips-investasi-saat-pandemi-corona-covid-19-fEPF 
Egeham, L. (2020). Covid-19 Pandemi Global, Bagaimana Protap dan Koordinasi Pusat-Daerah di Indonesia? Retrieved from dari Liputan6: https://www.liputan6.com/news/read/4201341/headline-covid-19-pandemi-globalbagaimana-protap-dan-koordinasi-pusat-daerah-di-indonesia

Fajar, M. A. (2019). Mengenal Pasar Modal Indonesia. 978-602-498-078-8.

Fama, E. F., Cochrane, J. H., \& Moskowitz, T. J. (2017). The Fama Portfolio: Selected Papers of Eugene F. Fama. Chicago: University of Chicago Press.

Fatikhah, S. A., \& Puryandani, S. (2020). Faktor Penentu Bid-Ask Spread Saham LQ45. EconBank: Journal Economics and Banking, 43-54.

Febrianti, N. (2014). Analisis Perbedaan Bid-Ask Spread dan Volatilitas Saham Sebelum dan Sesudah Pengumuman Stock Split. Jurnal Bisnis dan Manajemen Vol. 7 No. 1, 17-25.

Hartono, J. (2017). Teori Portofolio dan Analisis Investasi (11 ed.). Yogyakarta: BPFE.

Historical Data. (2020). Retrieved from YahooFinance: https://finance.yahoo.com/quote/TLKM.JK/history?p=TLKM.JK

Huang, C., Wang, Y., Li, X., Ren, L., Zhao, J., Zang, L., \& Fan, G. (2020). Clinical Features of Patients Infected with 2019 Novel Coronavirus in Wuhan, China. The Lancet.

Husnan, S. (2015). Dasar-Dasar Teori Portofolio \& Analisis Sekuritas (5th ed.). Yogyakarta: UPP STIM YKPN.

IDX. (2020). Index. Retrieved from Indonesian Stock Exchange: https://www.idx.co.id/produk/indeks/

Imelda, Siregar, H., \& Anggraeni, L. (2014). Abnormal Return and Trading Volume in the Indonesian Stock Market in Relation to the Presidential Elections in 2004, 2009, and 2014. International Journal of Administrative Science \& Organization, 21, 65-76.

Juliana, I. (2020). Mengenal dan Mencegah Virus Corona. Retrieved from RSUP dr. Soeradji Tirtonegoro: https://rsupsoeradji.id/mengenal-dan-mencegah-virus-corona/\#

Kim, J., Kim, J., Lee, S. K., \& Tang, L. (2020). Effects of Epidemic Disease Outbreaks on Financial Performance of Restaurants: Event Study Method Approach. Journal of Hospitality and Tourism Management, 32-41.

Maulina, V., \& Rusno. (2011). Bid-Ask Spread dan Periode Kepemilikan Saham pada Perusahaan LQ-45. Modernisasi, 7, 239-265.

Melati, D. A., Saryadi, \& Widiartanto. (2015). Analisis Reaksi Pasar Modal Atas Peristiwa Pemilihan Presiden 9 Juli 2014 (Event Study pada Indeks Saham LQ-45). Jurnal IImu Administrasi Bisnis, vol. 4, 284-294.

Nasarudin, M. I., Surya, I., Yustiavandana, I., Nefi, A., \& Adiwarman. (2014). Aspek Hukum Pasar Modal Indonesia. Jakarta: Kencana.

Noya, A. B. (2018). Memahami Epidemiologi dan Istilah-istilahnya. Retrieved from ALODOKTER: https://www.alodokter.com/memahami-epidemiologi-dan-istilah-istilahnya

OJK. (2020). Kebijakan Stimulus OJK dan Self-Regulatory Organization (SRO) Jaga Keberlangsungan Aktifitas Perdagangan di Pasar Modal.

OJK. (2020). Undang-Undang Republik Indonesia Nomor 8, Tahun 1995, tentang Pasar Modal.

Ong, E. (2016). Technical Analysis for Mega Profit. Jakarta: PT Gramedia Pustaka Utama.

Perhimpunan Dokter Paru Indonesia. (2020). Pneumonia COVID-19: Diagnosis \& Penatalaksanaan di Indonesia. Jakarta: PDPI.

Pransuamitra, P. A. (2020, Maret 14). Pekan Horor Bagi Bursa Saham Global, IHSG Terburuk Sejak 2008. Retrieved from Indonesia: 
https://www.cnbcindonesia.com/market/20200314080856-17-144845/pekan-hororbagi-bursa-saham-global-ihsg-terburuk-sejak-2008

Prasiska, Y., \& Nuzula, N. F. (2018). Analisis Abnormal Return dan Bid-Ask Spread Sebelum dan Sesudah Stock Split. Jurnal Administrasi Bisnis (JAB), 59, 61-67.

Putri, D. N., Sadalia, I., \& Irawati, N. (2020). Analysis of LQ45 Stock Market Index Reaction on Precidential Election 2019. International Journal of Research and Review, 463-472.

Ramli, R. R. (2020). Corona Dinyatakan sebagai Pandemik Penyebab IHSG Anjlok Hari Ini.

Retrieved from KOMPAS.com: https://money.kompas.com/read/2020/03/12/133639626/corona-dinyatakan-sebagaipandemik-penyebab-ihsg-anjlok-hari-ini

Ringkasan Saham. (2020). Retrieved from IDX: https://www.idx.co.id/data-pasar/ringkasanperdagangan/ringkasan-saham/

Rofiki, D., Topowijono, \& Nurlaily, F. (2018). Reaksi Pasar Modal Indonesia Akibat Peristiwa Pemilihan Gubernur DKI Jakarta Putaran II 2017. Jurnal Administrasi Bisnis, 185-193.

Saham Gain. (2016). Mengenal Spread Bid-Offer di Pasar Saham. Retrieved from Saham Gain: http://www.sahamgain.com/2016/10/Mengenal-spread-dengan-bid-offer-di-pasar.html

Sina, P. G. (2016). Financial Contemplation Part 2. Guepedia.

Subroto, B. (2014). Pengungkapan Wajib Perusahaan Publik: Kajian Teori dan Empiris. Malang: UB Press.

Suganda, T. R. (2018). Event Study: Teori dan Pembahasan Reaksi Pasar Modal Indonesia. Malang: Seribu Bintang.

Sugiyono. (2017). Metode Penelitian Kuantitatif, Kualitatif dan R\&D. Bandung: Alfabeta.

Tandelilin, E. (2010). Portofolio dan Investasi: Teori dan Aplikasi. Yogyakarta: Kanisius.

Thirzano, Y. (2020). Update 17 Maret 2020: Kasus Covid-19 di Indonesia Jadi 172 Orang. Retrieved from Tribunnews.com: https://www.tribunnews.com/corona/2020/03/17/update-17maret-2020-kasus-covid-19-di-indonesia-jadi-172-orang

Utama, C. A. (2012). Jenis Industri, Kepemilikan Saham Asing, dan Reaksi Pasar Modal Akibat Serangan Bom Teroris. Jurnal Akuntansi dan Keuangan Indonesia, 100-116.

Wang, Z., Qiang, W., \& Ke, H. (2020). A Handbook of 2019-nCoV Pneumonia Control and Prevention. China: Hubei Science and Technology Press.

WHO. (2020). WHO Director-General's opening remarks at the media briefing on COVID-19. Retrieved from WHO: https://www.who.int/dg/speeches/detail/who-director-general-sopening-remarks-at-the-media-briefing-on-covid-19 11-march-2020

Worldometer. (2020, March 2). Coronavirus Update (Live): 82,166 Cases and 3,061 Deaths from COVID-19 Wuhan China Virus Outbreak. Retrieved from Worldometer: https://www.worldometers.info/coronavirus/

Yuliana. (2020). Coronavirus disease (Covid-19); Sebuah tinjauan literatur. Wellnes and Healthy Magazine, 2, 187-192. 